\title{
Dimethyl sulfoxide effects on the febrile response to lipopolysaccharide injection in rabbits
}

[Efeitos do dimetil sulfóxido sobre a resposta febril induzida pela injeção de lipopolissacarídeo em coelhos]

\author{
A.H. Souza ${ }^{1}$, C.A.A. Valadão $^{1 *}$, M.A. Selegatto ${ }^{1}$, R.M. Almeida $^{2}$, M. Macari ${ }^{1}$ \\ ${ }^{1}$ Faculdade de Ciências Agrárias e Veterinárias - UNESP \\ Via de acesso Prof. Paulo Donato Castellane, s/n \\ 14884-900 - Jaboticabal, SP \\ ${ }^{2}$ Departamento de Medicina Veterinária - UPIS - Brasília, DF
}

\begin{abstract}
The present study was designed to determine whether DMSO causes an inhibition on the development of fever in rabbits. The intravenous administration of LPS $\left(1.5 \mu \mathrm{g} . \mathrm{kg}^{-1}\right.$ body weight $)$ caused fever in both saline+LPS and DMSO+LPS group, but the onset and magnitude of the induced fever were significantly different. The saline+LPS group presented a prototypic biphasic fever whereas the DMSO+LPS group presented an attenuated febrile response, but it was not abolished. These results suggest that DMSO may provide a protective mechanism against pyrogen LPS, probably through the modulation of NF- $\kappa \mathrm{B}$ mediated events, such as fever.
\end{abstract}

Keywords: LPS, fever, DMSO, rabbits

\section{RESUMO}

Estudaram-se os efeitos do DMSO na resposta febril induzida pela administração intravenosa de LPS em coelhos. A administração intravenosa de LPS $\left(1,5 \mu \mathrm{g} . \mathrm{kg}^{-1}\right.$ peso vivo) causou febre mesmo na presença do DMSO. No entanto, o inicio e a magnitude da febre induzida foram significativamente menores no grupo tratado com DMSO enquanto o LPS isolado induziu resposta febril bifásica. Estes resultados sugerem que o DMSO pode exercer um mecanismo protetor contra a ação pirogênica do LPS, provavelmente por meio da modulação dos eventos mediados pelo $N F-\kappa B$, entre eles, a febre.

Palavras-chave: LPS, febre, DMSO, coelhos

\section{INTRODUCTION}

Endotoxemia is caused by the release of LPS into the bloodstream inducing activation of the inflammatory cascade which can lead to septic shock. Fever is the most important manifestation of the acute phase of the immune response following infection. Generally, it is believed that fever is mediated by endogenous pyrogens, such as IL-1 $\beta$, peripherally induced by LPS (Atkins, 1960; Dinarello, 1984). Indeed, there is a great evidence indicating that circulating LPS is cleared by various resident macrophages, particularly by Kupffer cells, leading these cells to synthesize and release cytokines essentials for activating the febrile response to circulating LPS (Sehic et al., 1997).

Several studies have been conducted to understand the mechanism of transcriptional regulation of cytokines. The NF- $\kappa \mathrm{B}$ protein was described as a transcriptional factor recognizing an originally DNA sequence motif within the immunoglobulin $\kappa$ gene enhancer (Gimble and Max, 1987; Grimm and Baeuerie, 1993). NF-кBbinding sites, that regulate transcription initiation from a wide variety of gene promoters, have been identified including those of TNF (Collart et al., 1990; Sung et al., 1991) and IL-6 (Liebermann et al., 1990; Brach et al, 1993).

Recebido em 3 de março de 2007

Aceito em 5 de março de 2008

* Autor para correspondência (corresponding author)

E-mail: valadão@fcav.unesp.br 
Once activation of NF- $\kappa \mathrm{B}$ is dependent of changes in the oxidation state into the nucleus of the cell, the presence of antioxidants can inhibit LPS and cytokine induction by NF- $\kappa \mathrm{B}$ in different types of cells (Israel, et al., 1992; Grimm \& Baeuerie, 1993; Ivanov et al., 1993). Thus, it seems that NF- $\mathrm{KB}$ serves as a common target for oxidant compounds which influence cellular functions associated with immune defense.

DMSO is considered an effective free radical scavenger (Kharasch and Thyagarajan, 1983; Brackett et al., 1991; DeForge et al., 1992). Recent investigations demonstrated that DMSO inhibited LPS-induced TNF- $\alpha$ release and reduced TNF- $\alpha$ mRNA levels. Additionally, DMSO also suppressed the LPS induced NF- $\mathrm{BB}$ activation in a murine macrophage cell line (Nakamuta et al., 2001).

DMSO has been proved to inhibit the activation of $\mathrm{NF}-\kappa \mathrm{B}$, and this inhibition has been shown to reduce cytokines release. The main goal of this study was to evaluate the effects of DMSO on the fever response when administered before induction of experimental LPS-induced endotoxemia in rabbits.

\section{MATERIAL AND METHODS}

Male New Zealand White rabbits $(2.5-3.5 \mathrm{~kg})$ were used in this study. Before the experiments, the rabbits were individually housed in standard metal cages and maintained at $24-28^{\circ} \mathrm{C}$ under natural light conditions of approximately $14 \mathrm{~h}$ light and $10 \mathrm{~h}$ dark per day. The rabbits were offered food and water ad libidum. In order to minimize errors in body temperature measurements due to restraint stress, all rabbits were trained to adapt to the stocks for six hours every other day, from at least 10 days before the start of the experiment.

The animals were randomly assigned to one of the three treatments: LPS control group $(n=6)$ (saline+LPS $\left.{ }^{1}\right) ;$ DMSO control group $(n=6)$ (DMSO+saline) and DMSO pretreated group $(n=6) \quad(D M S O+L P S)$. LPS was diluted with pyrogen-free saline and i.v. injected at the dose

${ }^{1}$ LPS, E. coli, 055:B5, Sigma Chemical Co., St. Louis, MOUSA. of $1.5 \mu \mathrm{g} . \mathrm{kg}^{-1}$ body weight according to Gardeylevassort et al., 1977. DMSO was prepared at a concentration of $10 \mathrm{mg} / \mathrm{ml}$ in pyrogen-free saline and i.v. injected ten minutes before LPS or saline injection. The injections were made via the marginal ear vein using a sterile needle (25 gauge). All agents were infused at a volume adjusted to $100 \mu 1$.

On the day of the experiment, the animals were minimally restrained in conventional rabbit stocks at an ambient temperature of $25^{\circ} \mathrm{C} \pm 1$ from 9a.m. to 4p.m. Throughout the experiment, the rectal temperature was measured by a thermistor ${ }^{2}$ inserted $100 \mathrm{~mm}$ deep into the rectum and taped to the tail. One hour before and over six hours after pyrogen injection, rectal temperature was measured every 15 minutes with a telethermometer ${ }^{3}$. The increment in rectal temperature after pyrogen injection was calculated as the difference between the rectal temperature before and at different times after LPS injection. The rectal temperature in each animal was allowed to stabilize for at least 60 minutes before any injection was made.

At the end of the experimental period, the animals were sacrificed with an overdose of i.v. sodium pentobarbital (Murakami et al., 1990).

Statistical differences among groups were calculated by one-way ANOVA followed by the Student-Newman-Keuls test with the level of significance set at $\mathrm{P}<0.05$. Statistical differences among the fever curve points for each group were determined by one-way RM ANOVA followed by the Student-Newman-Keuls test with the level of significance set at $\mathrm{P}<0.05$.

\section{RESULTS}

The febrile responses in saline+LPS and DMSO+LPS groups to i.v. LPS injection are represented in Fig. 1. The latency to increase the rectal temperature, after pyrogen injection, was shorter in the saline+LPS group than DMSO+LPS group (30 minutes and 45 minutes, respectively). The febrile response in the saline+LPS group was represented by a dramatic increase in the rectal temperature three to four

\footnotetext{
${ }^{2}$ Thermistor (n701)Yellow Spring Instruments Co, Yellow Springs, OH-USA

${ }^{3}$ Telethermometer model 46TUC/YSI probe, Yellow Spring Instruments Co, Yellow Springs, OH-USA
} 
hours after LPS injection. The DMSO+LPS group showed a moderate increase in body temperature beginning one hour and a half after LPS injection and lasting 150 minutes. In both groups, the rectal temperature remained higher until six hours in compared to the baseline values. The LPS injection caused a typical biphasic febrile response in the saline+LPS group with the first and second peak recorded at
$75(1.4 \pm 0.6)$ and 210 minutes $(2.2 \pm 0.4)$ after injection, respectively. The increase in rectal temperature induced by LPS after DMSO treatment was less intense and it was sustained over the six-hour-experimental period without presenting a standard biphasic fever. DMSO+saline group had no changes in the body temperature (data not showed).

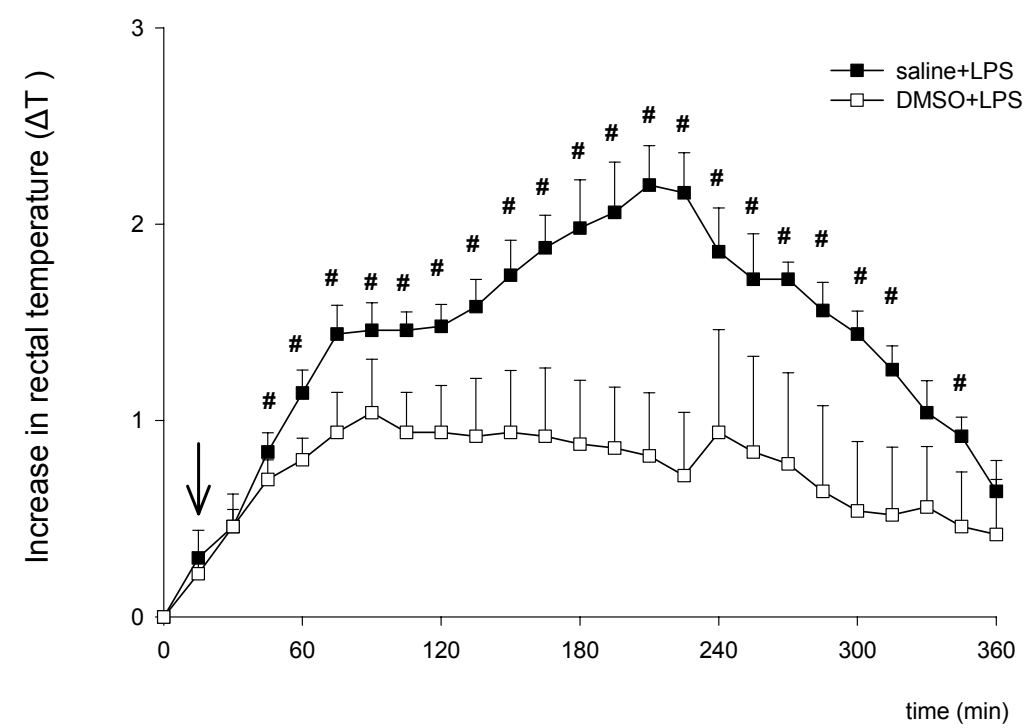

Figure 1. Febrile response of saline or DMSO pretreated rabbits after lipopolysaccharide (LPS) injection during a six-hour-observation period.

\# Significance between groups $(\mathrm{P}<0.05)$.

Arrow indicates LPS administration.

\section{DISCUSSION}

The results clearly demonstrated that DMSO significantly attenuated the fever induced by the i.v. injection of LPS. It is known that intravenous injection of LPS causes fever with an increase in the IL-1 $\beta$, IL-6 and TNF- $\alpha$ level (Long, 1990; Kugler, 1991; Kugler et al., 1995; Blatteis and Sehic, 1997; Kozak et al., 1998; Luheshi, 1998; Cartmell et al., 1999; Cartmell et al., 2000; Cartmell et al., 2001). The fever and increased levels of related cytokines were attenuated when LPS stimulated peripheral mononuclear cells were incubated with NF- $\kappa \mathrm{B}$ inhibitors (Lee et al., 2003). These findings were indicative that NF$\kappa \mathrm{B}$ activation was correlated with LPS-induced synthesis and release of cytokines (mainly IL-1 $\beta$ ) from peripheral mononuclear cells triggering fever.
Kelly et al. (1994), working with primary peritoneal macrophages, established a link between the LPS response and NF- $\kappa \mathrm{B}$ activation, which occurs parallel with the cytokine genes production. It was demonstrated that this response to LPS was partially inhibited by pretreatment with DMSO, indicating that antioxidants can modulate LPS-induced cytokine production in macrophages mediated by NF- $\kappa$ B. The addition of $2 \%$ DMSO reduced the intensity of the LPS-inducible NF- $\kappa \mathrm{B}$ complex, but not abolished it. In the same way, the present study showed a decreased febrile response in DMSO pretreated group, but did not abolish it. It could be considered that the less intense febrile response observed in DMSO+LPS group could be related with the known antioxidant effect of DMSO on the LPS response. In resting cells, NF$\kappa \mathrm{B}$ resides in the cytoplasm associated with $\mathrm{I} \kappa \mathrm{B}$, an inhibitor (Grimm and Baeuerie, 1993). When 
cells are activated by LPS, or chemical agents, the I $\mathrm{B}$ protein is degraded, thereby activating the DNA-binding ability of NF- $\kappa \mathrm{B}$ and freeing it for transport into the nucleus (Henkel et al., 1993). Moreover, a study showed that this regulation of $\mathrm{NF}-\mathrm{\kappa B}$ activation occurs by the changes in the oxidation state of the cell (Grimm and Baeuerie, 1993).

Thus, the current work suggests that a protective mechanism of DMSO against pyrogen (LPS) probably occurs by the modulation of NF- $\mathrm{KB}$ mediated events, such as production and release of cytokines related with the febrile response.

\section{ACKNOWLEDGMENTS}

This work was supported by the Coordenação de Aperfeiçoamento de Pessoal de Nível Superior CAPES-PROAPP - Ministério da Educação do Brasil.

This study was approved by the local ethics committee on animal experimentation: "Comissão de Ética na Experimentação da Faculdade de Ciências Agrárias e Veterinárias UNESP, Jaboticabal, SP”.

\section{REFERENCES}

ATKINS, E. Pathogenesis of fever. Physiol Rev., v.40, p.580-646, 1960.

BLATTEIS, C.M.; SEHIC, E. Fever: how many circulating pyrogens signal the brain? News Physiol. Sci., v.12, p.1-9, 1997.

BRACH, M.A.; GRUSS, H.S.; KAISHO, T. et al. Ionizing radiation induces expression of interleukin- 6 by human fibroblast involving activation of nuclear factor $\kappa \mathrm{B}$. J. Biol. Chem. v.268, p.8466-8472, 1993.

BRACKETT, D.J.; LERNER, M.R.; WILSON, M.F. et al. Dimethyl Sulfoxide antagonizes hypotensive, metabolic, and pathologic response induced by endotoxin. Circ. Shock., v.33, p.156$163,1991$.

CARTMELL, T.; LUHESHI, G.N.; ROTHWELL, N.J. Brain sites of action of endogenous interleukin-1 in the febrile response to localized inflammation in the rat. J. Physiol., v.518, p.585-594, 1999.
CARTMELL, T.; POOLE, S.; TURNBULL, A.V. et al. Circulating interelukin- 6 mediates the febrile response to localized inflammation in rats. J. Physiol., v.526, p.653-661, 2000.

CARTMELL, T.; LUHESHI, G.N.; HOPKINS, S.J. et al. Role of endogenous interleukin-1 receptor antagonist in regulating fever induced by localized inflammation in the rat. J. Physiol., v.531, p.171-180, 2001.

COLLART M.A.; COLLART, M.A.; BAEUERLE, P.; VASSALLI, P. et al. Regulation of tumor necrosis factor $\alpha$ transcription in macrophages: involvement of four $\kappa \mathrm{B}$-like motifs and of constitutive and inducible forms of NF-кB. Mol. Cell. Biol., v.10, p.1498-1506, 1990.

DEFORGE L.E.; FANTONE, J.C.; KENNEY, J.S. et al. Oxygen radical scavengers selectively inhibit interleukin-8 production in human whole blood. J. Clin. Invest., v.90, p.2123-2129, 1992.

DINARELLO C.A. Interleukin-1 and the pathogenesis of the acute-phase response. New Engl. J. Med., v.311, p.1413-1418, 1984.

GARDEY-LEVASSORT, C.; TANGUY, O.; LECHAT, P. Brain concentrations of biogenic amines and their metabolites in two types of pyrogen-induced fever in rabbits. J. Neurochem., v.28, p.177-182, 1977.

GIMBLE, J.M.; MAX, E.E. Human Immunoglobulin $\kappa$ gene enhancer: chromatin analysis at high resolution. Mol. Cell. Biol., v.7, p.15-25, 1987.

GRIMM S.; BAEUERIE P.A. The inducible transcription factor NF- $\mathrm{B}$ : structure-function relationship of its protein subunits. Biochem. J., v.290, p.297-308, 1993.

HENKEL, T.T. Rapid proteolysis of I $\mathrm{I} B-\alpha$ is necessary for the activation on transcription factor NF-кB. Nature, v.365, p.182-185, 1993.

ISRAEL, N.; GOUGEROT-POCIDALO, M.A.; AILLET F. et al. Redox status of cells influences constitutive or induced NF- $\mathrm{BB}$ translocation and HIV long terminal repeat activity in human $\mathrm{T}$ and monocytic cell lines. J. Immunol., v.49, p.3386-3393, 1992.

IVANOV, V.; MERKENSCHLAGER, M.; CEREDIG, R. et al. Antioxidant treatment of thymic organ cultures decreases NF- $\mathrm{BB}$ and TCF1 $(\alpha)$ transcription factor activities and 
inhibits alpha and beta $\mathrm{T}$ cell development. $J$. Immunol., v.151, p.4694-4704, 1993.

KELLY, A.K.; HILL, M.R.; YOUKHANA, K.; et al. Dimethyl sulfoxide modulates NF- $\kappa B$ and cytokine activation in lipopolysaccharide-treated murine macrophages. Infect. Immun., v.62, p.3122-3128, 1994.

KHARASCH, N.; THYAGARAJAN, B.S. Structural basis for biological activities of Dimethyl Sulfoxide. Ann. N. Y. Acad. Sci., v.411, p.391-402, 1983.

KLUGER, M.J. Fever: role of pyrogens and cryogens. Physiol. Rev., v.71, p.93-127, 1991.

KLUGER, M.J.; KOZAK, W.; LEON, L.R. et al. Cytokines in fever. Neuroimmunomodulation, v.2, p.216-223, 1995.

KOZAK, W.; KLUGER, M.J.; SOSZYNSKI, D. et al. IL-6 and IL-1 in fever: studies using cytokines-deficient (knockout) mice. Ann. N. Y. Acad. Sci., v.856, p.33-47, 1998.

LEE, J.J.; HUANG, W.T.; SHAO, D.Z. et al. Blocking NF- $\kappa b$ activation may be an effective strategy in the fever therapy. J. J. Physiol., v.53, p.367-375. 2003.

LIEBERMANN, T.A.; BALTIMORE, D. Activation of interleukin-6 gene expression through the NF- $\kappa \mathrm{B}$ transcription factor. Mol. Cell. Biol., v.10, p.2327-2334, 1990.

LONG, N.C.; OTTERNESS, I.; KUNKEL, S. et al. Roles of interleukin-1 $\beta$ and tumor necrosis factor in lipopolysaccharide fever in rats. Am. J. Physiol., v.259, p.R724-R727, 1990.

LUHESHI, G.M. Cytokines and fever. Ann. N. Y. Acad. Sci., v.856, p.83-89, 1998.

MURAKAMI, N.; SAKATA, Y.; WATANABE, $T$. et al. Central action sites of intreleukin-1 $\beta$ for inducing fever in rabbits. J. Physiol., v.428, p.299-312, 1990.

NAKAMUTA, M.; OHTA, S.; TADA, S. et al. Dimethyl Sulfoxide inhibits dymethylnitrosamine-induced hepatic fibrosis in rats. Int. J. Mo. Med., v.8, p.553-560, 2001.

SEHIC, E.; HUNTER, W.S.; UNGAR, A.L. et al. Blockade Kupffer cells prevent the febrile and preoptic prostaglandin $\mathrm{E}_{2}$ responses to intravenous lipopolysaccharide in guinea pig. Ann. N. Y. Acad. Sci., v.856, p.327-337, 1997.

SUNG, S.J.; WALTERS, J.A.; HUDSON, J. et al. Tumor necrosis factor $\alpha$ mRNA accumulation in human myelomonocytic cell lines. Role of transcriptional regulation by DNA sequence motifs and mRNA stabilization. J. Immunol., v.147, p.2047-2054, 1991. 